\title{
Effectiveness of triple inhalation therapy and non-invasive ventilation in the treatment of acute exacerbated chronic obstructive pulmonary disease
}

\author{
Zhang Lin, Nie Xiuhong ${ }^{\star}$, Luo Zhiming, Wei Bing, Teng Guojie \\ Department of Respiratory Medicine, Xuanwu Hospital Capital Medical University, Beijing, China
}

${ }^{*}$ For correspondence: Email: tz1174@163.com

Sent for review: 11 October 2018

Revised accepted: 27 December 2018

\begin{abstract}
Purpose: To determine the clinical effectiveness of combining triple inhalation therapy with noninvasive ventilation in treating acute exacerbated chronic obstructive pulmonary disease (AECOPD). Methods: A total of 128 AECOPD patients admitted in the Department of Respiratory Medicine of our Hospital were involved in the study. Two groups of patients were used (64 patients per group). The study group was given triple inhalation therapy and non-invasive ventilation, while only non-invasive ventilation was given to the control group. The curative effects of the two treatments and their effects on arterial $\mathrm{Pa}_{\mathrm{CO} 2}$ (partial pressure of carbon dioxide), $\mathrm{pH}$ and $\mathrm{Pa}_{\mathrm{O} 2}$ (partial pressure of oxygen) were determined.

Results: The study group showed significantly higher treatment effectiveness than the control group ( $p$ $<0.05)$. Post-treatment $\mathrm{Pac02}, \mathrm{pH}, \mathrm{Pa} \mathrm{a}_{\mathrm{o}}$, respiratory rate and heart rate differed significantly between the two groups $(p<0.05)$. Improvements in the five indices were more in the study group than in the control group $(p<0.05)$.

Conclusion: Combining triple inhalation therapy with non-invasive ventilation in the treatment of $A E C O P D$ enhances therapeutic effect, improves pulmonary ventilation, and reduces side effects.
\end{abstract}

Keywords: Chronic obstructive pulmonary disease, Acute exacerbation, Triple inhalation, Non-invasive ventilation

\footnotetext{
This is an Open Access article that uses a funding model which does not charge readers or their institutions for access and distributed under the terms of the Creative Commons Attribution License (http://creativecommons.org/licenses/by/4.0) and the Budapest Open Access Initiative (http://www.budapestopenaccessinitiative.org/read), which permit unrestricted use, distribution, and reproduction in any medium, provided the original work is properly credited.
}

Tropical Journal of Pharmaceutical Research is indexed by Science Citation Index (SciSearch), Scopus, International Pharmaceutical Abstract, Chemical Abstracts, Embase, Index Copernicus, EBSCO, African Index Medicus, JournalSeek, Journal Citation Reports/Science Edition, Directory of Open Access Journals (DOAJ), African Journal Online, Bioline International, Open-J-Gate and Pharmacy Abstracts

\section{INTRODUCTION}

Chronic obstructive pulmonary disease (COPD) is an emphysema and/or chronic bronchitis with airflow obstruction, which can develop into pulmonary heart disease and respiratory failure. The global incidence of COPD in people over 40 years old is 9 to $10 \%$ [1]. Epidemiological studies have revealed that COPD ranks third amongst fatal diseases in China, inferior only to malignant tumors and cerebrovascular diseases $[2,3]$. Acute exacerbation of chronic obstructive pulmonary disease (AECOPD) results in high rate of hospitalization and morbidity, and the disease progresses so quickly during this period that it leads to high mortality rate if not timely treated [4]. The present study investigated the effectiveness of combining triple inhalation 
therapy with non-invasive ventilation in the treatment of 128 AECOPD cases.

\section{METHODS}

\section{Patient information}

A total of 128 AECOPD patients seen in Xuanwu Hospital Capital Medical University from April 2016 to December 2016 were assigned (without bias) to control and observation groups (64 per group). In the study group, there were 33 men and 31 women aged 50 to 81 years (mean $=65$ \pm 10.5 years), with disease course ranging from 6 to 20 years (mean $=9.9 \pm 1.5$ years). In the control group, there were 35 males and 29 females, aged from 51 to 79 years (mean age = $65 \pm 10.6$ years), with a disease course of 5 to 21 years (mean $=10.5 \pm 2.1$ years). There were no significant differences in sex, age, and duration of AECOPD between both groups $(p>0.05)$. All patients signed informed consent.

This research received approval from the Ethical section of Department of Respiratory Medicine, Xuanwu Hospital, Capital Medical University (approval no. 201810306), and was carried out according to the guidelines of Declaration of Helsinki promulgated in 1964 as amended in 1996 [5].

\section{Treatments}

The control group underwent non-invasive ventilation. Expiratory pressure was adjusted based on the disease status of each patient, and oxygen flow was set to $3.5 \mathrm{~L} / \mathrm{min}$ in case of excessive or insufficient oxygen flow. The relevant parameters were gradually and slowly regulated downward after the patients were stable with blood oxygen saturation over $95 \%$.

Apart from non-invasive ventilation, the observation group was given triple inhalation therapy. The drugs and their applications were: 1 $\mathrm{mg}$ budesonide aerosol (AstraZeneca, specifications: 100 whiffs $/ 5 \mathrm{ml}$, batch no. 227664) bid plus $2.5 \mathrm{mg}$ salbutamol aerosol (GlaxoSmithKline, specifications: $100 \mathrm{mg} / \mathrm{press}$, 200 presses, batch no. 970801), bid, plus $500 \mu \mathrm{g}$ Ipratropium bromide aerosol (Boehringer Ingelheim Pharma $\mathrm{GmbH} \&$ Co. /KG, specifications: $2 \mathrm{ml} /$ bottle, batch number: R281134), $500 \mu \mathrm{g}$, bid. The treatment duration for both groups was seven days.

\section{Study indices and criteria for assessment of effectiveness}

Arterial blood gas indices of the patients, viz, $\mathrm{Pa}_{\mathrm{CO} 2}, \mathrm{pH}$, and $\mathrm{Pa}_{\mathrm{O} 2}$ were determined before and after treatment, as well as respiratory rate and heart rate. The criteria for assessment of effectiveness were: 1 = marked effect: symptoms and signs like respiratory rate and heart rate subsided and all indices were normal; $2=$ effective: symptoms, signs, and indices were improved without adverse reaction; $3=$ ineffective: there was no improvement, or there was exacerbation.

\section{Statistical analysis}

The software, Epidata 3.03, was used for data entry and logical error correction, while the data were analyzed by SPSS 20.0 software, and are expressed as mean \pm standard deviation (SD). Differences were compared using $t$-test. Ranked data were compared with rank sum test. Values of $p<0.05$ were assumed as indicative of statistical significance of differences.

\section{RESULTS}

\section{Clinical effectiveness}

Treatment effectiveness was significantly higher in the study group than in the control group $(p<$ 0.05 , Table 1).

Table 1: Clinical effectiveness data $(N=64)$

\begin{tabular}{lcccc}
\hline $\begin{array}{l}\text { Grou } \\
\mathbf{p}\end{array}$ & $\begin{array}{c}\text { Marke } \\
\text { dly } \\
\text { effecti } \\
\text { ve }\end{array}$ & $\begin{array}{c}\text { Effecti } \\
\text { ve }\end{array}$ & $\begin{array}{c}\text { Ineffecti } \\
\text { ve }\end{array}$ & $\begin{array}{c}\text { Total } \\
\text { effectiven } \\
\text { ess (\%) }\end{array}$ \\
\hline $\begin{array}{l}\text { Contr } \\
\text { ol } \\
\text { group }\end{array}$ & 19 & 28 & 17 & 73.44 \\
$\begin{array}{l}\text { Study } \\
\text { group }\end{array}$ & 23 & 35 & 7 & $90.63^{\mathrm{a}}$ \\
\hline${ }^{a} P<0.05$, compared with control & &
\end{tabular}

\section{Clinical indices}

Pre-treatment $\mathrm{Pa}_{\mathrm{CO} 2}, \mathrm{pH}, \mathrm{Pa}_{\mathrm{O} 2}$, respiratory rate, and heart rate in the two groups were comparable $(p>0.05)$. However, post-treatment $\mathrm{Pa}_{\mathrm{CO} 2}, \mathrm{pH}, \mathrm{Pa}_{\mathrm{O} 2}$, respiratory rate, and heart rate differed significantly between the two groups $(p<$ 0.05 ). The study group had higher degrees of improvements in these indices than the control group, as shown in Table 2.

\section{DISCUSSION}

Obstructive pulmonary disease (OPD) is characterized by progressive exacerbation of airflow limitation. Exacerbation of airflow limitation may worsen the structural damage to respiratory tract wall and give rise to irreversible airflow limitation and dysfunction in pulmonary 
ventilation [6,7]. Clinically, COPD is classified into stable COPD and acute exacerbation of COPD (AECOPD). The clinical features of AECOPD are aggravated expectoration and cough, aggravated polypnea and wheezing, very sticky sputum, and increased sputum volume, all of which worsen the airflow limitation and induce life-threatening dyspnea [9,10]. Medications, controlled oxygen therapy, and ventilation support are used for the treatment of AECOPD.

Table 2: Arterial blood gas, heart rate, and respiratory rate before and after treatment (mean \pm SD)

\begin{tabular}{lcccc}
\hline \multirow{3}{*}{ Index } & \multicolumn{2}{c}{ Study group } & \multicolumn{2}{c}{ Control group } \\
\cline { 2 - 5 } & $\begin{array}{c}\text { Pre- } \\
\text { treatme } \\
\boldsymbol{n t}\end{array}$ & $\begin{array}{c}\text { Post- } \\
\text { treatme } \\
\boldsymbol{n} \boldsymbol{t}\end{array}$ & $\begin{array}{c}\text { Pre- } \\
\text { treatme } \\
\boldsymbol{n t}\end{array}$ & $\begin{array}{c}\text { Post- } \\
\text { treatme } \\
\boldsymbol{n} \boldsymbol{t}\end{array}$ \\
\hline Pao2 & $45.2 \pm$ & $73.1 \pm$ & $43.5 \pm$ & $57.7 \pm$ \\
& $5.8^{*}$ & $8.3^{* \Delta}$ & 6.3 & $7.9^{\Delta}$ \\
$\mathrm{Pa} 02$ & $68.3 \pm$ & $43.5 \pm$ & $65.7 \pm$ & $53.6 \pm$ \\
& $8.7^{*}$ & $7.1^{* \Delta}$ & 9.7 & $6.8^{\Delta}$ \\
$\mathrm{pH}$ & $7.15 \pm$ & $7.41 \pm$ & $7.16 \pm$ & $7.31 \pm$ \\
& $0.13^{*}$ & $0.15^{* \Delta}$ & 0.17 & $0.21^{\Delta}$ \\
Heart rate & $117.5 \pm$ & $91.3 \pm$ & $114.7 \pm$ & $97.7 \pm$ \\
Respirato & $15.7^{*}$ & $10.8^{* \Delta}$ & 12.4 & $8.7^{\Delta}$ \\
ry rate & $51.4 \pm$ & $19.3 \pm$ & $52.1 \pm$ & $35.5 \pm$ \\
\hline${ }^{*} P>0.05$, & $6.5^{*}$ & $5.7^{* \Delta}$ & 7.8 & $6.7^{\Delta}$ \\
\hline
\end{tabular}

treatment; ${ }^{*} p<0.05$, compared with control group post-treatment; ${ }^{\Delta} p<0.05$, compared with itself preand post-treatment

Non-invasive ventilation (NIV) method uses a respirator to conduct positive pressure ventilation through mouth or nose mask to connect the patient. The operation is simple in clinical settings: there are no artificial airways, making it readily acceptable to patients, and it has lower risk of airway infection. However, it requires that the patient should be conscious and it is not very conducive for the drainage of airway secretions.

Currently, non-invasive positive pressure ventilation is generally used for mild or moderate respiratory failure. The best situation for applying non-invasive ventilation is where the patient has respiratory mechanical abnormalities and respiratory muscle fatigue but sputum drainage is relatively less important $[11,12]$. Aerosol inhalation therapy can direct drugs to bronchia and lung, and it has such advantages as faster onset of effect, lower dose and less adverse reaction when compared with oral intravenous systemic medication [13]. Thus, it has been the first choice for the treatment of AECOPD.

Budesonide is currently the only secondgeneration inhaled adrenal hormone that efficiently binds airway cortisol receptors to exert an explicit anti-infective effect [14]. Some researchers have reported that the combination of glucocorticoid and $\beta_{2}$-agonists has a significant synergistic effect, and that salbutamol can reduce the drug dose by sensitization of hormonal receptor, while budesonide enhances activation of airway $\beta_{2}$ receptor [7]. In addition, ipratropium bromide combined with salbutamol acts on $\beta_{2}$ and $M_{3}$ receptors of the respiratory system together and then enlarges the bronchia [15].

The findings of this study show that the effectiveness of the observation group was much higher than that of the control group. This suggests that combining triple inhalation therapy with assisted non-invasive ventilation is able to improve the clinical symptoms and signs in AECOPD such as expectoration, cough, and dyspnea, with a significant advantage of controlling respiratory tract infection. Posttreatment $\mathrm{Pa}_{\mathrm{CO} 2}, \mathrm{pH}$, and $\mathrm{Pa}_{\mathrm{O} 2}$, respiratory rate and heart rate differed significantly between the two groups, with greater improvements in the observation group. This implies that the combination therapy was effective in reducing airway resistance, thereby improving pulmonary ventilation.

\section{Limitations of the study}

The sample population used in this study was small. Moreover, the study was based on patients from the same hospital. In future studies, a multi-center study involving a higher population of patients is desirable. Moreover, adverse reactions were not evaluated in the present study. This should be included in subsequent investigations.

\section{CONCLUSION}

The combination of triple inhalation therapy with assisted non-invasive ventilation facilitates treatment of AECOPD by relieving clinical symptoms and signs and improving pulmonary ventilation, without increasing the risk of adverse reactions.

\section{DECLARATIONS}

\section{Conflict of Interest}

No conflict of interest associated with this work.

\section{Contribution of Authors}

We declare that this work was done by the author(s) named in this article and all liabilities pertaining to claims relating to the content of this article will be borne by the authors. All authors 
read and approved the manuscript for publication. Nie Xiuhong conceived and designed the study. Zhang Lin, Nie Xiuhong, Luo Zhiming, Wei Bing, Teng Guojie collected and analyzed the data, while Zhang Lin wrote the manuscript.

\section{REFERENCES}

1. Wang K, Qi XY, LUTT. Clinical efficacy evaluation of ivabradine in treatment of patients with stable angina pectoris complicated with chronic obstructive pulmonary disease. Chin J New Drugs Clin Remedies 2018; 3(1): 53-57.

2. Matera MG, Calzetta L, Cazzola M. $\beta$-Adrenoceptor Modulation in Chronic Obstructive Pulmonary Disease: Present and Future Perspectives. Drugs 2013; 73 (15): 1653-1663.

3. Wakabayashi K, Ikeda N, Kajimoto $K$, Minami $Y$, Keida $T$, Asai K, Munakata R, Murai K, Sakata Y, Suzuki H, et al. Trends and predictors of non-cardiovascular death in patients hospitalized for acute heart failure. Int $J$ Cardiol 2018; 250: 164-170.

4. Chinese Thoracic Society, Chinese Medical Association. Guidelines on treatment and diagnosis of chronic obstructive pulmonary disease (revised edition 2007). Chin J Tubere Respir Dis 2007; 30 (1): 199-233.

5. World Health Organization. Declaration of Helsinki. Br Med J 1996; 313(7070): 1448-1449.

6. Mao WW, Jiang YQ, Ouyang LL, Wang W, Wu W. Early diagnostic values of $C D 64$ and $C D 11 b$ indices of peripheral white blood cells for acute exacerbation of chronic obstructive pulmonary disease in older adults. Chin J Cell Mol Imm 2014; 30 (11): 1201-1203.

7. Dong GR, Wang YX. Analysis on effect of combination therapy of salbutamol, ipratropium bromide, and in treating COPD acute exacerbation. Chin Remed Clin 2014; 14 (5): 691-692.

8. Ding JH, Shen YB, Wang T, Liu C. Research of switching point for sequential invasive to noninvasive ventilation in the treatment of AECOPD. J Clin Pulmo Med 2015; 18 (12): 2223-2226.

9. Wang B, Dou ZX, Li XL. Value of noninvasive positive pressure ventilation for the treatment of COPD acute exacerbation. J Mudanjiang Med Univ 2016; 9 (2): 7374.

10. Liao XW, Chen YM, Liao ML, He JY. Impact of lung infection degree on the efficacy of non-invasive ventilation in treatment of acute exacerbation of COPD complicating respiratory failure. Clin Med Engin 2016; 8 (4): $501-502$.

11. Qi YL. Application of BiPAP mode of non-invasive ventilation for the treatment of COPD acute exacerbation with respiratory failure. Aerospace Medicine 2015; 19 (6): 718-719.

12. Zhao ZL, Liu YL. Analysis on efficacy of non-invasive positive pressure ventilation in treating AECOPD with pulmonary encephalopathy. J Clin Med Prac 2015; 2 I (17): 80-81.

13. Li YF. Inhalation of ipratropium bromide and ambroxol hydrochloride for the treatment of 35 cases with AECOPD. Chin Pharm 2013; 22(5): 63-65.

14. Wu X. Clinical effect of aerosol inhalation of pulmicort respules combined with compound ipratropium bromide solution for inhalation in treating asthmatic bronchitis. Chin J Clin Rational Drug Use 2018; 2(3): 3-4.

15. Hou Y, Li JD, Xue QL, Liu W, Chen WQ, Wang W. Comparison on efficacy and side-effect of budesonide plus ipratropium bromide or salbutamol for the treatment of chronic obstructive pulmonary disease. Clin J Med Officer 2015; 43(2): 123-125, 138. 